\title{
Perspectives on the South African Responsible Lending Regime and the Duty to Conduct Pre-agreement Assessment as a Responsible Lending Practice
}

\author{
Corlia Van Heerden* and Stéfan Renke** \\ Department of Mercantile Law, Faculty of Law, University of Pretoria, Pretoria, South Africa
}

\begin{abstract}
In the 2001 INSOL International Consumer Debt Report: Report of Findings and Recommendations, the view was held that the solution to overspending and over-indebtedness is inter alia to be found in the idea that prevention is better than cure. Ex ante responsible lending practices as preventative measures to avoid reckless credit granting and over-indebtedness are arguably more important tools in establishing a healthy credit market than ex post measures. The focus of this contribution, is therefore, to provide a detailed overview of the South African reckless credit regime as a debt- prevention measure aimed at promoting responsible lending, with specific focus on the aspect of pre-agreement assessment as a core mechanism to avoid reckless credit granting and over-indebtedness. The main features of the reckless credit regime are highlighted, and afterwards, a detailed exposition of the evolution and extensive recent development of the pre-agreement assessment component in South Africa is undertaken. Finally, observations are made regarding the South African reckless regime in general and with regard to affordability assessment specifically and its ability, benchmarked against the essential features of a responsible lending regime as advocated by Wilson in the book 'International responses to issues of credit and over-indebtedness in the wake of crisis', to promote responsible lending. The conclusion is reached that benchmarked against the four characteristics of an effective responsible lending regime as identified by Wilson, it is apparent that the South African reckless lending regime is no 'toothless tiger', and that it attaches the necessary amount of significance to the credit provider's duty to take reasonable steps to do a proper pre-agreement assessment in order to avoid reckless credit granting.
\end{abstract}

*E-mail: corlia.vanheerden@up.ac.za;

**E-mail: stefan.renke@up.ac.za 


\section{Introduction}

The ongoing worldwide recession did not leave the South African economy untouched. Statistics released by the institution responsible for the regulation of the consumer credit market in South Africa, the National Credit Regulator, ${ }^{1}$ show that South African consumers incur high levels of consumer credit debt. ${ }^{2}$ A great number of these consumers become over-indebted as a result of their credit debt or are at least experiencing difficulties in servicing such debts. This is underscored by the fact that out of the 21.71 million credit-active consumers credit bureaus recorded, 9.60 million $^{3}$ had impaired credit records at the end of March 2014. ${ }^{4}$ It is also disconcerting that many South African consumers are exposed to adverse shocks, for instance, a rise in interest rates, and therefore to the risk of becoming over-indebted in future. ${ }^{5}$

In the INSOL International Consumer Debt Report: Report of Findings and Recommendations (2001), ${ }^{6}$ the view was held that the solution to overspending and over-indebtedness is inter alia to be found in the idea that prevention is better than cure. ${ }^{7}$ In the context of the prevention of over-indebtedness, responsible lending practices by credit providers play a pivotal role in avoiding consumers getting caught in a debt trap, which leaves them locked into a vicious cycle of overindebtedness. It is thus of paramount importance for a country which seeks to

1. See, for instance, National Credit Regulator, Credit Reports (December 2011-September 2013)-available at www.ncr.org.za 'accessed 18 August 2014'. Quarter-to-quarter and year-on-year comparisons in these reports make it possible to ascertain trends in the credit market, such as an increase (or decrease) in total credit extension. For instance, R107.60 billion new credit was granted for the quarter ended December 2011, R109.62 billion for the quarter ended June 2013 and R117.21 billion for the quarter ended September 2013. The statistics also differentiate between different types of credit products. It should be noted that mortgages account for a substantive percentage of these amounts. It should also be noted that the statistics provided by the National Credit Regulator only reflect credit that is granted by registered credit providers.

2. The total outstanding gross debtors book of consumer credit for the quarter ended September 2013, for instance, amounted to R1.49 trillion National Credit Regulator (n 1).

3. In other words $44,2 \%$.

4. National Credit Regulator, Credit Bureaux Monitor (Quarter March 2014)-available at www.ncr.org.za 'accessed 18 August 2014'. The information is for the quarter ended March 2010 to the quarter ended March 2014. It is interesting to note that at the end of September 2007, shortly after the National Credit Act came into effect, out of 16.9 million credit-active consumers, 6.38 million (or $37,75 \%$ ) were credit impaired-National Credit Regulator.

5. The net wealth position of households (according to $\mathrm{S}$ Walters et al, Quarterly Bulletin of the South African
Reserve Bank (December 2011) 69, available at https:// www.resbank.co.za/Lists/News $\% 20$ and $\% 20$ Publications/ Attachments/4899/01Full\%20Quarterly\%20Bulletin.pdf, 'accessed on 18 August 2014', the net wealth of households represents the difference between the total assets and liabilities in the household sector. A household is better equipped to withstand or absorb sudden shocks in the economy or a fall in income if there is an increase in its net wealth position. This, in turn, has an effect on the household's capacity to borrow and thus to spend or invest. Reflecting on recent trends in South Africa, Walters et al. sound the following warning: 'With the growth in household debt outpacing that in household assets, the ratio of household debt to total assets advanced from 16,6 per cent at the end of 2003 to 19,1 per cent at the end of 2010, suggesting that South African households over time became more vulnerable to changes in lending interest rates and conditions.') and debt to income ratios the ratio of household debt to disposable income was $74.3 \%$ in the 4 th quarter of 2013, which is high. See the Quarterly Bulletin of the South African Reserve Bank (March 2014) 11, available at https://www.resbank.co.za/Lists/ News $\% 20$ and $\% 20$ Publications/Attachments/6140/ 01 Full $\% 20$ Quarterly $\% 20$ Bulletin $\% 20 \%$ E2 $\% 80 \%$ 93\%20March\%202014.pdf, 'accessed on 18 August 2014') serve as indicators.

6. Hence the 'INSOL Report (2001)'-29.

7. See also the Report of the Committee Consumer Credit, chaired by lord Crowther vol 1 and 2 Cmnd 4596 Her Majesty's Stationery Office, London (1971) 377-hence, the 'Crowther Report'. 
pursue the financial welfare of its consumers in the credit market to ensure that it maintains an effective responsible lending regime with sufficient ex ante as well as ex post measures to avoid irresponsible credit granting and to provide debt relief to over-indebted consumers. In this regard, ex ante responsible lending practices as preventative measures to avoid reckless credit granting and over-indebtedness are arguably more important tools in establishing a healthy credit market than ex post measures, which merely serve as attempts to restore the health of a credit market plagued by irresponsible lending - thus, addressing the causes of over-indebtedness are to be preferred over merely treating the symptoms of irresponsible lending practices, which practices are often the root cause of such over-indebtedness. ${ }^{8}$ Responsible lending practices cover a wide array of measures that can be implemented as preventative interventions, such as consumer education and promotion of financial literacy, responsible marketing, regulation of the cost of credit and pre-agreement screening or assessment of consumers. ${ }^{9}$

Wilson has recently, in the excellent book 'International responses to issues of credit and over-indebtedness in the wake of crisis', ${ }^{10}$ made certain significant remarks pertaining to responsible lending practices which can be used in order to benchmark the efficiency of lending regimes in the ongoing battle against irresponsible lending. In describing a pro-active responsible lending regime, she indicates that the goal of any responsible lending practice should be first and foremost to protect consumers from the harms of irresponsible lending, in that way, avoiding over-indebtedness for individuals, as well as the broader economic consequences of that over-indebtedness, including financial crisis. ${ }^{11}$ She points out that a potential shortcoming of a responsible lending regime is that it will be interpreted in such a way that it leads to restrictive lending practices, which exacerbate financial exclusion. ${ }^{12}$ In this regard, she validly cautions that responsible lending regimes should not encourage restrictive lending practices any more than they should allow for lax lending practices, pointing out that the main cause of over-restrictive lending practices seems to be inflexible credit assessment methods. ${ }^{13}$ She further indicates that there is evidence that low-income individuals can indeed repay loans, provided that they are given the chance to do so through an appropriate, individualistic credit assessment process and provided the loan term and repayments are structured so that borrowers can repay them without substantial hardship. ${ }^{14}$ She accordingly remarks that if a responsible lending regime is not structured to

8. It is acknowledged that there are also many instances where consumers become over-indebted, not as a result of irresponsible lending practices, but because of, for example, changes in their personal circumstances such as illness or retrenchment or death of a family member who contributed to the household expenses.

9. Stéfan Renke, 'An evaluation of debt prevention measures in terms of the National Credit Act 34 of
2005' (LLD thesis, University of Pretoria 2012) ch 8hence, Renke LLD thesis.

10. T Wilson in T Wilson (ed), International responses to issues of credit and over-indebtedness in the wake of crisis, Ashgate (2013).

11. Wilson (n 10) 126.

12. Wilson (n 10) 126.

13. Wilson (n 10) 127.

14. Wilson (n 10) 127. 
encourage individualised credit assessment, then it is likely to lead to overrestrictive lending practices and to exacerbate over-indebtedness. ${ }^{15}$

Wilson also points out that where problems of over-indebtedness and financial crisis are attributed to a failure on the part of consumers to behave responsibly in relation to the credit contracts into which they choose to enter, by for instance failing to make full and true disclosure of their financial positions to credit providers, a logical regulatory response might seem to be to punish such behaviour. ${ }^{16}$ However, this arguably ignores a structural cause of over-indebtedness, namely, a credit market where consumers are excluded from access to mainstream credit providers and have no real choice regarding the agreements that they enter into. ${ }^{17}$

Wilson uses four criteria to assess the likely effectiveness of responsible lending regimes which she validly posits should be evidenced by a pro-active, rather than a reactive regulatory approach. ${ }^{18}$ These criteria are as follows:

(a) a focus on responsible lending in order to avoid over-indebtedness, rather than responsible borrowing;

(b) a focus on consumer credit in general, not limited to residential mortgage loans;

(c) an encouragement of flexible, individualised credit assessment practices, or at least not an encouragement of rigid and inflexible credit assessment practices; and

(d) the existence of a regulatory agency charged with enforcement, which is adequately resourced to properly monitor and enforce compliance with market conduct regulation, including responsible lending obligations.

A number of jurisdictions are evaluated by Wilson with regard to the likely effectiveness of their responsible lending regimes, namely Australia, the United States, Europe and South Africa. ${ }^{19}$ Although Wilson makes some valid remarks regarding the South African responsible lending regime, the very brief overview that she provides of this regime lacks important detail with the result that it may, with respect, provide a distorted picture thereof.

The purpose of this contribution is therefore to provide a detailed overview of the South African reckless credit regime as a debt-prevention measure aimed at promoting responsible lending, with specific focus on the aspect of pre-agreement assessment as a core mechanism to avoid reckless credit granting and overindebtedness. The main features of the reckless credit regime will be highlighted, and afterwards, a detailed exposition of the evolution and extensive recent development of the pre-agreement assessment component will be undertaken. This discussion will deal with the recent spate of draft assessment guidelines, which were

15. Wilson (n 10) 128. In this regard, she also refers to Ramsay 'From truth in lending to responsible lending' in G Howells, A Janssen and R Schulze (eds), Information rights and obligations: a challenge for party autonomy and transactional fairness, Ashgate (2005) 59, where he noted a conflict between standardised models of credit scoring and truly responsible lending and stated ' $[\mathrm{t}]$ he responsible lending standard envisages a more individualised lending process, perhaps based on a meeting with the borrower. Credit scoring, however, permits a lender to grant credit without ever meeting the borrower.'

16. Wilson (n 10) 123.

17. Wilson (n 10) 123.

18. Wilson (n 10) 128.

19. For a brief overview of the salient features of these regimes as identified and discussed by Wilson (n 10) see 113-116 (Australia), 116-117 (US), 117-118 (Europe) and 118-119 (South Africa). 
followed up with draft assessment regulations, amendments to the National Credit Act and also the introduction of Credit Amnesty Regulations. Observations will be made regarding the South African reckless credit regime in general and with regard to affordability assessment specifically and its ability, benchmarked against the essential features of a responsible lending regime as advocated by Wilson, to promote responsible lending.

\section{The National Credit Act and Responsible Lending}

The National Credit Act, ${ }^{20}$ which came into full effective operation on 1 June 2007, provides the regulatory framework for the South African credit market. A number of problems were identified in respect to the legislative framework that preceded the National Credit Act, rendering the reform thereof necessary. ${ }^{21}$ The framework was inter alia dated, ineffective and characterised by the over-supply of credit to those members of society who were deemed to be creditworthy, ${ }^{22}$ while, by contrast, the majority of the population had no access to reasonably priced credit. ${ }^{23}$ Many consumers were consequently faced with heavy debt burdens. ${ }^{24}$ South Africa's consumer credit regulatory framework therefore had to be brought into line with the best practice in other jurisdictions. ${ }^{25}$ The drafters of the new consumer credit policy framework that gave rise to the National Credit Act, with reference to the credit legislation that was current at the time, made the unequivocal statement that 'South African law provides no effective protection against over-indebtedness... ${ }^{26}$ The drafters ascribed overindebtedness inter alia to reckless lending and borrowing and stated that ' $\mathrm{r}$ ] eckless credit extension will be curbed by introducing a general requirement that all credit providers should do affordability assessments prior to approving any credit facility'. ${ }^{27}$ The committee that did the credit law review preceding Policy Framework (2004) proposed that 'the focus should be shifted from price control to protection against over-indebtedness, and to the regulation of predatory lending practices. ${ }^{28}$

The National Credit Act gave effect to the aforementioned objectives and has added a new dimension to credit regulation in South Africa by promoting

20. 34 of 2005-hence, the 'National Credit Act', the 'NCA' or the 'Act'.

21. See in general the Department of Trade and Industry South Africa 'Consumer Credit Law Reform: Policy Framework for Consumer Credit', (August 2004) 1213, available at www.ncr.org.za, 'accessed on 1 September 2014'-hence, 'Policy Framework (2004)'. See also Report prepared for FinMark Trust, South Africa by RP Goodwin-Groen (with input from M Kelly-Louw), 'The National Credit Act and its regulations in the context of access to finance in South Africa', (November 2006) 12-14, available at http://www.finmark.org.za/ wp-content/uploads/NCA_regulations.pdf, 'accessed on 1 September 2014'.

22. A concept which, as remarked by Wilson at (n 10) 124 , is 'value-laden' and may lead to an interpretation which blames the consumer for not being 'worthy' of a loan.

23. Policy Framework (2004) (n 21) 13.

24. Policy Framework (2004) (n 21) 12-13.

25. Policy Framework (2004) (n 21) 13.

26. Policy Framework (2004) (n 21) 30.

27. Policy Framework (2004) (n 21) 31.

28. See Memorandum on the objects of the National Credit Bill, 2005, available at http://www.google.co. za/url?url=http://www.gov.za/documents/download. $\mathrm{php} \% 3 \mathrm{Ff} \% 3 \mathrm{D} 66032 \& \mathrm{rct}=\mathrm{j} \& \mathrm{frm}=1 \& \mathrm{q}=\&$ esrc $=\mathrm{s} \& \mathrm{sa}=$ U\&ei=J2IEVMeOCYiUau-vgfAL\&ved=0CDAQFjAF \&sig2=2h17HT88NB3NNTryzjx83g\&usg=AFQjCNF T6uY5BQSGu8P3mtUsypmke8E1WQ' 'accessed on 1 September 2014', 100 ff. 
responsible lending practices through the introduction in Part D of Chapter 4 of the Act, of novel measures aimed at preventing reckless credit granting and over-indebtedness, and debt relief measures to deal with the consequences of reckless credit granting and over-indebtedness. ${ }^{29}$

Reckless credit granting and over-indebtedness as provided for in the National Credit Act may only be raised by natural person consumers with the result that only natural persons may access the debt relief offered in respect of reckless credit and over-indebtedness. ${ }^{30}$ Reckless credit granting specifically cannot be raised in respect of pre-existing credit agreements that were entered into before the Act came into operation. ${ }^{31}$ It can be raised in respect of a wide range of credit agreements, secured and unsecured. ${ }^{32}$ It can, however, not be raised in respect of the following types of credit agreements: a school loan or a student loan, an emergency loan, a public interest credit agreement, a pawn transaction, an incidental credit agreement or a temporary increase in the credit limit under a credit facility. ${ }^{33}$

The National Credit Act identifies and prohibits three types of reckless credit granting in respect whereof debt relief may be obtained. ${ }^{34}$ Section $80(1)$ accordingly provides that a credit agreement is reckless if, at the time that the agreement was made, or when the amount improved in terms of the agreement is increased (other than an increase in a credit facility in terms of section 119(4)) ${ }^{35}$

29. The concepts 'reckless credit' and 'overindebtedness' are new to South African credit legislation and were not previously addressed under the Act's predecessors, the Usury Act 73 of 1968 and the Credit Agreements Act 75 of 1980. JM Otto and R-L Otto, The National Credit Act Explained 3rd edn, LexisNexis (2013) 64 refer in this regard to the 'second chance' given to over-committed consumers. See also in general M Kelly-Louw, 'The prevention and alleviation of consumer overindebtedness', (2008) 20 SA Merc LJ 200; PN Stoop, 'South African consumer credit policy: measures indirectly aimed at preventing consumer overindebtedness', (2009) 21 SA Merc LJ 365; JM Otto, 'Die oorbelaste skuldverbruiker: die Nasionale Kredietwet verleen geensins onbeperkte vrydom van skulde nie', (2010) 2 TSAR 399; S Renke, 'Measures in South African consumer credit legislation aimed at the prevention of reckless lending and overindebtedness: an overview against the background of recent developments in the European Union', (2011) 74 THRHR 208; Renke LLD thesis (n 9) 413. 30. S 78(1) of the National Credit Act excludes the application of Part D of Ch 4 from a credit agreement in respect of which the consumer is a juristic person. In terms of $s 79$ of the Act, a consumer is over-indebted if the preponderance of available information at the time that a determination is made indicates that the consumer is or will be unable to satisfy in a timely manner all the obligations under all credit agreements to which the consumer is a party, having regard to the consumer's financial means, prospects and obligations and probable propensity to satisfy in a timely manner all the obligations under all the credit agreements to which the consumer is a party as indicated by the consumer's history of debt repayment.

31. Item 4(2) of Sch 3 to the NCA. This is due thereto that neither the Usury Act 73 of 1968 nor the Credit Agreements Act 75 of 1980 contained any provisions obliging the credit provider to do a pre-agreement assessment along the lines envisaged by s 81 of the NCA, prior to entering into a credit agreement with a consumer.

32. These agreements include credit facilities and various types of credit transactions (including mortgage agreements) as well as suretyships entered into by natural persons in respect of credit agreements to which the Act applies. See s 8 of the Act read with ss 1 and 4 regarding the scope of application of the Act. See also Otto and Otto (n 29) 19-35 and PN Stoop, 'Kritiese evaluasie van die toepassingsveld van die National Credit Act', (2008) De Jure 352.

33. S 78(2) of the NCA. The aforesaid exclusions are subject to the proviso that any credit extended in terms of a school or student loan, an emergency loan or a public interest credit agreement is inter alia reported to the $\mathrm{Na}$ tional Credit Register. For the reasons or probable reasons for these exclusions, see Renke LLD thesis (n 9) $415-416$. For the definitions of the various types of credit agreements mentioned in s 78(2), see s 1 of the NCA.

34. Arguably a fourth type of reckless credit is envisaged by s 88(4), where a consumer who is subject to a debt re-arrangement is granted further credit while such re-arrangement still subsists.

35. S119(4) deals with the automatic annual increase of the credit limit of a credit facility that a consumer may request at the time of application for the credit facility. 
(a) the credit provider failed to conduct an assessment as required by section 81(2), irrespective of what the outcome of such an assessment might have been at the time; or

(b) the credit provider, having conducted an assessment as required by section 81(2), entered into the credit agreement with the consumer despite the fact that the preponderance of information available to the credit provider indicated that

(i) the consumer did not generally understand or appreciate his risks, costs or obligations under the proposed credit agreement; or

(ii) entering into that (specific) credit agreement would make the consumer overindebted.

Accordingly, with regard to the first type of reckless credit, the credit provider's failure to conduct a pre-agreement assessment before extending credit to the consumer is inexcusable, and the credit extended is per se reckless. ${ }^{36}$ The second type of reckless credit is regarded as reckless because, even though the credit provider conducted a pre-agreement assessment, it disregarded the fact that the preponderance of available information indicated that the consumer was generally ignorant regarding the risks, costs and obligations under the credit agreement. The third type of reckless credit refers to the situation where despite the fact that a pre-agreement assessment was carried out which indicated that the granting of credit under the specific credit agreement would topple the consumer into the abyss of overindebtedness, the credit provider disregarded such information and nevertheless extended the ill-fated credit. The appropriate time period with regard to which an assessment must be made of whether credit was granted recklessly, is the time of conclusion of the specific credit agreement. ${ }^{37}$

The National Credit Act is pro-active with regard to its objectives to promote responsible lending, as it not only prohibits reckless credit but also imposes peremptory pre-agreement assessment requirements in order to avoid reckless credit granting. Both credit providers and consumers are obliged to cooperate in the prevention of reckless credit: the credit provider by doing a proper assessment as mandated by the Act prior to extending credit and the consumer by answering fully and truthfully during the assessment. This is evident from section 81(2)(a) of the Act, which prohibits a credit provider from entering into a credit agreement without first taking reasonable steps to assess the proposed consumer's general understanding and appreciation of the risks and costs of the proposed credit, of his rights and obligations under a credit agreement as

36. The financial position of the consumer is irrelevant to this type of reckless credit.

37. S 80(2) provides that when a determination is to be made whether a credit agreement is reckless or not, the person making the determination must apply the criteria for reckless credit as contained in s 80(1) as they existed at the time the agreement was made and without regard for the ability of the consumer to meet the obligations under the agreement or understand or appreciate the risks, costs and obligations under the proposed credit agreement at the time that the determination is being made. This means that if the consumer has since entering a reckless credit agreement become able to afford the credit or educated on his risks, costs and obligations under the agreement, it does not negate the fact that the credit, at the time of conclusion of the agreement, was extended recklessly. Thus, granting of reckless credit cannot be remedied or ratified ex post the conclusion of the agreement. 
well as his debt repayment history as a consumer under credit agreements and his existing financial means, prospects and obligations. ${ }^{38}$ In addition, if the consumer applies for credit for a commercial purpose, it must be assessed whether there is a reasonable basis to conclude that such commercial purpose may prove to be successful. ${ }^{39}$

As regards the consumer's obligation to cooperate in the prevention of reckless credit granting, Section 81(1) provides that when applying for credit, and while that application is being considered by a credit provider, the prospective consumer must fully and truthfully answer any requests for information made by the credit provider as part of the assessment. It is a complete defence to an allegation of reckless credit if the credit provider establishes that the consumer failed to answer fully and truthfully any such request for information made by the credit provider and if a court or the National Consumer Tribunal determines that the consumer's failure to do so materially affected the ability of the credit provider to make a proper assessment. ${ }^{40}$ This complete defence against reckless credit is only available to a credit provider when both the aforementioned requirements are met, provided that the credit provider indeed took reasonable steps to conduct the assessment in accordance with the matters that should be considered for purposes of Section 81(2). ${ }^{41}$

38. S 78(3) provides that 'financial means, prospects and obligations', with respect to a consumer or prospective consumer, includes

(a) income, or any right to receive income, regardless of the source, frequency or regularity of that income, other than income that the consumer or prospective consumer receives, has a right to receive, or holds in trust for another person;

(b) the financial means, prospects and obligations of any other adult person within the consumer's immediate family or household, to the extent that the consumer, or prospective consumer, and that other person customarily;

(i) share their respective financial means; and

(ii) mutually bear their respective financial obligations; and

(c) if the consumer has or had a commercial purpose for applying for or entering into a particular credit agreement, the reasonably estimated future revenue flow from that business purpose'.

39. S 81(2)(b). See further Desert Star Trading 145 and Another v No 11 Flamboyant Edleen CC [2010] ZASCA 148 pars 14 and 15 .

40. S 81(4). For a detailed discussion of this defence see C Van Heerden and A Boraine, 'The money or the box: perspectives on reckless credit in terms of the National Credit Act 34 of 2005', (2011) De Jure 396-397 and 400; M Kelly-Louw, 'A credit provider's complete defence against a consumer's allegation of reckless lending', (2014) 26 SA Merc LJ 24 ff. See further Horwood v Firstrand Bank Ltd [2011] ZAGPJHC 121 (21 September 2011), where the court indicated (par 6) that as s 81(4) contains a requirement of materiality, it is accordingly not every failure by a consumer to fully and truthfully answer the credit provider's request as part of the prescribed assessment that entitles the credit provider to this complete defence.

41. Thus, if a consumer fails to answer fully and truthfully when a s 81 assessment is conducted but the aspects about which the consumer is not truthful does not materially affect the credit provider's ability to make an assessment, the complete defence against reckless credit is not available to the credit provider. In Horwood o Firstrand Bank (n 40) par 7 the court indicated that where a credit provider has taken the required 'reasonable steps to assess' the relevant matters referred to in $\mathrm{s} 81(2)$, the credit agreement is not a reckless one in terms of s $80(1)$, whether or not the assessment was tainted by a consumer's incomplete or untruthful answers. The court further remarked that the complete defence provided for in s $81(4)$ is a defence which may be raised in addition to one that the credit provider's assessment obligations under s 81 have been met. In Absa Bank Ltd v COE Family Trust and Others 2012 (3) SA 184 (WCG) at 189 the court indicated that s $81(4)$ needs to be read with s 81(2) with the effect that, if an assessment as contemplated by s $81(2)$ was not undertaken in the first place, then s 81(4) is of no relevance. It should thus be noted that the mere fact that an assessment was undertaken is not sufficient as prerequisite for the credit provider being able to raise a defence in terms of s 81(4). It is only where such an assessment meets the requirements of $\mathrm{s} 81(2)$ that a credit provider can thereafter competently invoke the provisions of s $81(4)$. 
It is submitted that the sanctions in respect of reckless credit granting also serve a preventative purpose and are not merely remedial in nature. As the focus of this contribution is on the role of the pre-agreement assessment in the prevention of reckless credit granting and over-indebtedness, a brief mention of the sanctions for reckless credit granting will suffice. Section 83(1) of the National Credit Act provides that despite any provision of law or agreement to the contrary, in any court proceedings in which a credit agreement is being considered, the court may declare that the credit agreement is reckless, as determined in accordance with Part D of Chapter 4. It thus appears that the court may suo motu raise the issue of reckless credit in such proceedings. ${ }^{42}$ The debt relief orders that the court (and now also the National Consumer Tribunal ${ }^{43}$ may order in respect of reckless credit are the following: ${ }^{44}$ if a court declares that a credit agreement is reckless in terms of Section 80(1)(a) (no prior credit assessment) or 80(1)(b)(i) (the consumer did not generally understand the risks, costs or obligations under the credit agreement), the court has the discretion to make an order setting aside all or part of the consumer's rights and obligations under that credit agreement, as the court determines just and reasonable in the circumstances. ${ }^{45}$ Alternatively, ${ }^{46}$ the court may suspend the force and effect of that credit agreement. ${ }^{47}$ In respect of the third type of reckless credit which causes the consumer to become over-indebted (as described in Section 80(1)(b)(ii)), once the court has declared the agreement reckless, it must further consider whether the consumer is over-indebted at the time of those court proceedings. ${ }^{48}$ If so, the court may make an order suspending the force and effect of that credit agreement until a date determined by it when making the order of suspension; and in terms of the order, it may also restructure the consumer's obligations under any other credit agreements. ${ }^{49}$

Because reckless credit constitutes prohibited conduct in terms of the National Credit Act, the National Consumer Tribunal is empowered to impose an administrative

\footnotetext{
42. C Van Heerden, 'Over-indebtedness and reckless credit' in JW Scholtz (ed), Guide to the National Credit Act (LexisNexis) 2008-11-9 et seq par 11.4.3-hence, 'Scholtz Commentary'.

43. S 25 of the National Credit Amendment Act 19 of 2014-hence, the 'NCA Amendment Act', also extends the powers to deal with reckless credit extension to the National Consumer Tribunal, established in terms of $\mathrm{s}$ 26 of the NCA. The NCA Amendment Act, although assented to by the President of South Africa on 26 March 2014, still has to be put into operation by the President-s 39 NCA Amendment Act. See also the succeeding citations.

44. For a detailed discussion of the powers of the court with regard to reckless credit, see Van Heerden (n 42) in Scholtz Commentary par 11.4.5; A Boraine and C Van Heerden, 'Some observations regarding reckless credit in terms of the National Credit Act 34 of 2005', (2010) (73) THRHR 651-654; Van Heerden and Boraine (n 40) 400-410. 45. S 83(2)(a).
}

46. The conjunctive 'or' is used between s 83(2)(a) and (b)

47. S 83(2)(b). For the effect of suspension of a credit agreement, see s 84 NCA.

48. S 83(3)(a).

49. S 83(3)(b). The restructuring is done in terms of $\mathrm{s}$ 87 which provides that the Magistrate's Court may re-arrange a consumer's obligations under a credit agreement and refers back to s 86(7)(c)(ii) which provides that such obligations may be re-arranged by extending the period of the agreement and reducing the amount of each payment due accordingly; postponing during a specified period the dates on which payments are due under the agreement; extending the period of the agreement and postponing during a specified period the dates on which payments are due under the agreement; or recalculating the consumer's obligations because of contraventions of Part A or B of Ch 5, or Part A of Ch 6. See further Van Heerden (n 42) in Scholtz Commentary 11-34 and 11-35. 
fine upon a credit provider who has granted credit recklessly. ${ }^{50}$ Such administrative fine may not exceed the greater of 10 per cent of the credit provider's annual turnover during the preceding financial year or $\mathrm{R} 1$ million. ${ }^{51}$ It is also a condition of the registration (licencing) as credit provider that such credit provider will not extend reckless credit, with the result that in addition to an administrative fine, a credit provider may also be at risk of having its registration cancelled if it engages in reckless credit granting. ${ }^{52}$ Clearly, the risk of having a credit agreement set aside or suspended and its registration cancelled as well as the reputational and financial risk associated with an administrative fine would deter at least some credit providers from recklessly extending credit.

The Section 81 pre-agreement assessment as required by the National Credit Act is pivotal in preventing credit being granted recklessly and causing the consumer to become over-indebted. From the matters that the credit provider is required to have regard to when conducting the Section 81 assessment, it is clear that the section envisages a comprehensive assessment which not only relates to affordability but also has regard to the consumer's ability to understand the consequences of obtaining credit and his credit repayment history. ${ }^{53}$ The National Credit Act initially did not contain any provisions detailing exactly how the assessment must be carried out, and apart from obliging the credit provider to have regard to the very broad considerations indicated in Section 81 during the preagreement assessment and imposing a duty on the consumer to answer truthfully during such assessment, no standard format for the assessment was prescribed.

Section $82(1)$ of the Act originally provided that a credit provider may determine for itself the evaluative mechanisms or models and procedures to be used in meeting its assessment obligations under Section 81, provided that any such mechanism, model or procedure results in a fair and objective assessment. This provision had to be read with Section 61(5), which provides that a credit provider may determine for itself any scoring or other evaluative mechanism or model to be used in managing, underwriting and pricing credit risk, provided that any such mechanism or model is not founded or structured upon a statistical or other analysis in which the basis of risk categorisation, differentiation or assessment is a ground of unfair discrimination, prohibited in Section 9(3) of the Constitution. ${ }^{54}$ Section 82(1) was subject to Section 82(2)(a), which provided that the National Credit Regulator could pre-approve the evaluative mechanisms, models and

50. S 151. In 2013 African Bank was found to have contravened the National Credit Act by extending credit recklessly and faced a hefty fine of R300 million which was subsequently settled by payment of an agreed amount of R20 million-Press releases, 'Media statement on African Bank Limited', available at www.ncr.org.za, 'accessed on 1 September 2014'. 51. S 151(2). See further s 151(3) for the factors to be taken into account in determining an administrative fine and s 151(4) read with reg 16(1) of the Regulations made in terms of the National Credit Act, 2005 Government Notice R 489 in Government Gazette
28864 of 31 May 2006-hence, the National Credit Regulations, regarding the determination of the credit provider's annual turnover.

52. S 48

53. Van Heerden and Boraine (n 40) 397.

54. S 9(3) of the Constitution of the Republic of South Africa, 1996 provides that the State may not unfairly discriminate directly or indirectly against anyone on one or more grounds, including race, gender, sex, pregnancy, marital status, ethnic or social origin, colour, sexual orientation, age, disability, religion, conscience, belief, culture, language and birth. 
procedures to be used in terms of Section 81 in respect of proposed developmental credit agreements. Section 82(2)(b) further provided that the National Credit Regulator could also publish guidelines proposing evaluative mechanisms, models and procedures, to be used in terms of Section 81, applicable to other credit agreements. A guideline published by the Regulator would, however, not be binding on a credit provider. ${ }^{55}$

It was also envisaged that the National Consumer Tribunal would play a role in ensuring that credit providers comply with their assessment obligations. In this regard, it was provided that if a credit provider repeatedly failed to meet its obligations under Section 81 or customarily used evaluative mechanisms, models or procedures that do not result in a fair and objective assessment, the Regulator could apply to the Tribunal for an order in terms of Section 82(4). If the Tribunal found the credit provider guilty, it could require that credit provider to apply any guidelines published by the Regulator in terms of Section 82(2)(b) or any alternative guidelines consistent with prevalent industry practice, as determined by the Tribunal. $^{56}$

Given that in the period between 1 June 2007, when the Act came into full effective operation, and the first quarter of 2013, no guidelines for the preassessment in terms of Section 81 were published by the National Credit Regulator, with the result that no matters relating to non-compliant assessment models served before the Tribunal and very few cases were reported relating to reckless credit granting it is clear that credit providers to a large extent had carte blanche in how they structured and conducted their Section 81 assessments. It is thus submitted that for the first couple of years that the Act was in operation and significantly during the global financial recess which started in 2008, the ability of the pre-agreement assessment as a measure to prevent reckless credit granting was stifled by the lack of guidelines or a more binding legal framework within which it had to be administered.

Due thereto that the Act did not lay down specific requirements other than the aforementioned broad aspects which had to be considered during the Section 81 assessment, the courts had to assist in providing some guidance on when a proper assessment for purposes of Section 81 could be said to have been conducted. In Horwood v Firstrand Bank $L t d,{ }^{57}$ it was held that whether or not a credit grantor has taken the required reasonable steps to meet its assessment obligations is in the light of the wording of Section 81(2) and 82(1), to be determined objectively on the facts and circumstances of any given case. In SA Taxi Securitisation (Pty) Ltd $v$ Mbatha ${ }^{58}$ the court, however, remarked that while one purpose of the National Credit Act is to discourage reckless credit, the Act is also designed to facilitate access to credit by borrowers who were previously denied such access. Consequently, an over-critical armchair approach by the court towards credit providers when

55. S 82(3), subject to s $82(2)(a)$ and $82(4)$. 56. S $82(4)(a)$ and (b).
57. Horwood v Firstrand Bank (n 40) par 5. 58. 2011 (1) SA 310 (GSJ). 
evaluating reckless credit or the imposition of excessive penalties upon lenders who have recklessly allowed credit would significantly chill the availability of credit, especially to the less affluent members of our society. ${ }^{59}$ In Absa Bank v COE Family Trust and Others, ${ }^{60}$ it was submitted on behalf of the credit provider that a particular clause in a mortgage loan agreement indicated that the defendants understood the risks and costs and the rights and obligations under the agreement. ${ }^{61}$ It was alleged that this agreement covered all the requirements for the prescribed assessment, and further, that it was not open to the defendants to raise a defence of reckless credit, because if it was established in terms of Section 81(4) that the consumer failed to fully and truthfully answer requests for information made by the credit provider, this was a complete 'response' (defence) by the credit provider to the averments of the defendants. ${ }^{62}$ The court considered the clause and indicated that there was no indication as to whether a request for information was made of any of the defendants by or on behalf of the plaintiff, whose request for information would have ensured that the credit process was undertaken in terms of the threepronged set of inquiries contained in Section 81(2). ${ }^{63}$ The court subsequently dismissed the application for summary judgment inter alia because it appeared that no assessment as contemplated by Section 81(2) was conducted with the result that the issue regarding whether the consumer answered truthfully or not as envisaged by Section $81(4)$ became of no relevance. ${ }^{64}$

The objective to encourage responsible lending in the South African credit market, specifically in the context of better regulation of affordability assessment (as one of the three prongs of the Section 81 assessment) in order to prevent reckless credit granting, eventually gained impetus when a joint media statement was issued by the Minister of Finance and the Chairperson of the Banking Association of South Africa (BASA) in November 2012 entitled 'Ensuring Responsible Market Conduct for Bank Lending', as a result of an agreement that was reached at a meeting on 19 October 2012 that BASA and its member banks would inter alia review their approach to the assessment of affordability. ${ }^{65}$ It was further agreed that BASA, the National Credit Regulator and the National Treasury would formulate a standard to measure affordability, which could then be incorporated into regulations as minimum standards. ${ }^{66}$ Following this, the National Credit Regulator

59. Par 37

60. Absa Bank v COE Family Trust (n 41) par 6.

61. The particular clause reads as follows:'The borrower states that

11.1 he undertakes his risks and costs, as well as his rights and obligations under this agreement; 11.2 entering into this agreement will not cause him to become over-indebted as contemplated in the National Credit Act;

11.3 he has fully and truthfully answered all and any requests for information made of him by or on behalf of the bank leading up to the conclusion of this agreement; 11.4 the bank has given the borrower a pre-agreement statement and the quotation.'
62. Par 7.

63. Par 11.

64. Par 12.

65. Joint Statement 'Ensuring Responsible Market Conduct for Bank Lending' (November 2012), available at http://www.treasury.gov.za/comm_media/ press/2012/2012110101.pdf, 'accessed on 24 July 2014'-hence, the 'Joint Statement'.

66. Joint Statement (n 65) 3. The said agreements and commitments relate only to the member banks of BASA but other credit providers such as non-bank micro-lenders and retailers, were also encouraged to conform to the good practices committed to by the Banks. 
issued a public notice ${ }^{67}$ in May 2013 in which certain draft affordability guidelines $^{68}$ (not regulations as per the aforementioned Joint Statement) were proposed, namely the following:

(a) credit applicants prove their claimed discretionary income when it is above the norm for a person with their gross income and that such norms be determined as a percentage of gross income bands;

(b) credit providers consider all the credit applicant's income, expenses and debt repayments when doing an affordability assessment;

(c) credit providers refrain from lending to the maximum of the consumer's discretionary income and leave a margin of at least 25 per cent of their discretionary income for adverse changes in the economy or the consumer's circumstances;

(d) credit providers use the credit applicant's current information as stored on one or more credit bureaus;

(e) credit providers process applications for credit within 7 days from assessing an applicant's credit information as stored on credit bureaus; and

(f) credit providers share credit application information on credit bureaus to allow for better affordability assessments to be made by other credit providers and to reduce credit application fraud.

The National Credit Regulator followed up on the May 2013 Draft Guidelines in a circular during September 2013 entitled 'Affordability Assessment Guidelines' ${ }^{69}$ The September 2013 Draft Guidelines were significantly more comprehensive than those that appeared in May $2013^{70}$ and would apply to all credit providers and to all credit agreements to which the Act applies, but not to a credit agreement in terms whereof the prospective consumer or consumer is a juristic person as defined in the Act. ${ }^{71}$ These Guidelines would also (in line with Section 78(2) of the Act) not apply to the following credit agreements: a developmental credit agreement, a school loan or a student loan, a public interest credit agreement, a pawn transaction, an incidental credit agreement, an emergency loan, a temporary increase in the credit limit under a credit facility, a unilateral credit limit increase under a credit facility in terms of Section 119(1), $119(4)$ and 119(5) of the Act and a pre-existing Credit Agreement in terms of Schedule 3 item 4(2) of the Act. It also provided that, where indicated, parts of the Guidelines would have limited application to secured credit agreements. ${ }^{72}$

A number of significant definitions not contained in the National Credit Act was introduced to facilitate the application of the September 2013 Draft Guidelines. ${ }^{73}$

67. Comments in the proposed guidelines were invited by 14 June 2013-see http://www.ncr.org.za/ press_release/Public $\% 20$ Notice $\% 20 . p d f$, 'accessed on 5 August 2014'. See also the 'Credit Provider's Code of Conduct to Combat Over-indebtedness', available at http://www.ncr.org.za/pdfs/Circulars/Code $\%$ 200f $\% 20$ Conduct $\% 20$ for $\% 20$ CPs.pdf.

68. Hence, the 'May 2013 Draft Guidelines'.

69. Or the 'September 2013 Draft Guidelines', available at www.ncr.org.za.

70. It was provided that the National Credit Regulator would notify credit providers of any amendment to the
Guidelines as well as the implementation periods by publishing them on its website and by sending them via email, facsimile or prepaid registered post to the contact details provided by credit providers to the Regulator.

71. September 2013 Draft Guidelines 3. Given that juristic person consumers are not entitled to the remedies relating to reckless credit it follows that the Guidelines would also not apply to them. 72. September 2013 Draft Guidelines 1.

73. September 2013 Draft Guidelines 2. 
'Joint prospective consumers or joint consumers' would mean the prospective consumers or consumers that are co-principal debtors and jointly and severally liable with regard to the same credit agreement and applies jointly for the credit agreement. Prospective consumers or consumers married in community of property that apply separately for a credit agreement and sureties were specifically excluded from the aforesaid definition. 'Discretionary income' was defined to mean gross income less statutory deductions (such as income tax and Unemployment Insurance Fund) less necessary expenses (at a minimum as defined in the Guidelines) less all other committed payment obligations including such obligations as may appear in the credit applicant's credit records as held by any credit bureau. ${ }^{74}$ 'Allocatable income' meant gross income less statutory deductions (such as income tax and Unemployment Insurance Fund) less necessary expenses (at a minimum as defined in the Guidelines) while 'allocatable income buffer' was defined to mean a percentage of the allocatable income which credit providers are required to allow for changes in the consumer's financial circumstances. 'Necessary expenses' referred to the prospective consumer's minimum living expenses in regard to food, transport and accommodation as determined in accordance with paragraph 5.2 of the Guidelines as discussed hereinafter. 'Unsecured term credit agreement' meant a credit transaction (excluding a pawn transaction; discount transaction, incidental credit agreement, instalment agreement, mortgage agreement, secured loan and lease), in respect of which the deferred amount is not secured by a pledge of movable property, cession of a thing of value or rights, mortgage over immovable property, suretyship or other personal security or a right in property other than credit insurance. 'Secured credit agreement' was defined as 'a credit agreement in respect of which the deferred amount is secured by a pledge of immovable property, cession of a thing of value or rights, mortgage over immovable property, suretyship or other personal security or a right in property other than credit insurance'.

The September 2013 Draft Guidelines stated that the assessment envisaged by Section 81 is more comprehensive than (merely) assessing the probability of default by a consumer ${ }^{75}$ and that the Guidelines were intended to establish 'calculation norms' for credit providers to take the reasonable steps in assessing the prospective consumer's existing financial means, prospects and obligations as contemplated in Section 81(2)(a)(iii) of the Act. ${ }^{76}$ Regarding the calculation of the consumer's means and prospects when concluding a Section 81 pre-agreement assessment, the September 2013 Draft Guidelines ${ }^{77}$ require credit providers to take reasonable steps to assess the prospective consumer's allocatable income as well as his discretionary income, to determine whether the consumer has the financial means and prospects to pay the proposed credit instalments. ${ }^{78}$ Credit providers are further required ${ }^{79}$ to take reasonable steps to validate income by referring to the prospective consumer's payslips and/or bank statements and/or by obtaining other credible information, either written

74. September 2013 Draft Guidelines 2. 75. September 2013 Draft Guidelines 3. 76. September 2013 Draft Guidelines 3. 77. 4.
78. This also applies to joint prospective consumers or joint consumers.

79. September 2013 Draft Guidelines 4. 
or electromagnetically recorded, of the prospective consumer's income. Where the prospective consumer's monthly income shows variance, the average income over the period of not less than 3 months preceding must be utilised. ${ }^{80}$

With regard to the calculation of existing financial obligations, ${ }^{81}$ Table $1^{82}$ is included in the September 2013 Draft Guidelines and reflects the minimum living expense norms (necessary expenses), broken down by annual gross income, that may be accepted by credit providers, absent evidence to the contrary, when credit providers calculate the existing financial obligations of prospective consumers in terms of Section 81(2)(a)(iii) of the Act. ${ }^{83}$ It was further provided that where prospective consumers claim to have transport, accommodation or food expenses which are cumulatively less than that set out in Table 1, they should be required by the credit provider to evidence their claimed lower necessary expenses by means of appropriate documentation. ${ }^{84}$ In respect of unsecured term credit agreements, credit providers are required to ensure that the prospective consumer discloses necessary expenses equal or exceeding those reflected in Table 1; alternatively, the credit provider must obtain credible written evidence that the prospective consumer's disclosed necessary expenses are below those set out in Table $1 .{ }^{85}$ The guidelines stipulated that any credit provider that enters into an unsecured term credit agreement with a consumer where such consumer's necessary expenses are below those set out in Table 1, without credible evidence in support of same,

80. This also applies to joint consumers or joint prospective consumers.

81. September 2013 Draft Guidelines 4 and 5. The aforementioned principles with regard to existing financial obligations also apply to joint prospective consumers or joint consumers.

82. After tax income percentage of monthly household income to be made available as a minimum for repayment of debt

\begin{tabular}{|c|c|c|c|}
\hline $\begin{array}{l}\text { Annual } \\
\text { gross } \\
\text { income }\end{array}$ & & $\begin{array}{c}\text { Annual } \\
\text { fixed } \\
\text { factor } \\
\text { (food, } \\
\text { transport, } \\
\text { accommodation) }\end{array}$ & $\begin{array}{c}\text { Annual } \\
\text { fixed } \\
\text { factor }+\% \\
\text { of income } \\
\text { above } \\
\text { band min } \\
(\%)\end{array}$ \\
\hline Min & Max & & \\
\hline R0 & $\begin{array}{l}\mathrm{R} 14,400 / / \\
\pm £ 820.80\end{array}$ & 0 & 100 \\
\hline $\begin{array}{l}\mathrm{R} 14,400.01 / \\
\pm f^{8} 820.80\end{array}$ & $\begin{array}{l}\mathrm{R} 75,000 / / \\
\pm \mathcal{E}^{4275}\end{array}$ & $\begin{array}{l}\mathrm{R} 14,400 / / \\
\pm £ 820.20\end{array}$ & 6.75 \\
\hline $\begin{array}{l}\mathrm{R} 75,000.01 / / \\
\pm \delta^{4275}\end{array}$ & $\begin{array}{c}\mathrm{R} 300,000 / / \\
\pm £_{1} 17100\end{array}$ & $\begin{array}{l}\mathrm{R} 18,500 / / \\
\pm £ 1054.50\end{array}$ & 9 \\
\hline $\begin{array}{l}\mathrm{R} 300,000.01 / / \\
\pm £_{17100}\end{array}$ & $\begin{array}{c}\mathrm{R} 600,000 / / \\
\pm £ 34200\end{array}$ & $\begin{array}{l}\mathrm{R} 40,500 / / \\
\pm £ 2308.50\end{array}$ & 8.2 \\
\hline $\begin{array}{l}\mathrm{R} 600,000.01 / / \\
\pm £ 34200\end{array}$ & High & $\begin{array}{l}\mathrm{R} 65,100 / / \\
\pm £ 3710.70\end{array}$ & 6.75 \\
\hline
\end{tabular}

83. Par 5.2.1. of the September 2013 Draft Guidelines. The following example was provided to illustrate how Table 1 operates: should the prospective consumer have an annual gross income of R24 000, the credit provider may not accept annual necessary expenses of less than R14 400 plus R648 (being $6.75 \%$ of R9 600) unless same is evidenced as required in the September 2013 Draft Guidelines. It was further provided that Table 1 will be periodically reviewed by the National Credit Regulator.

84. Par 5.2.2 of the September 2013 Draft Guidelines. 85. Par 5.2.3 of the September 2013 Draft Guidelines. The Guidelines mention that examples of credible evidence would include but would not be limited to payments reflected on bank statements, lease agreements, home loan statements, unencumbered deeds of title, personal credit records, vehicle leases or finance agreements, letters froma tribal authority or other similar documents. 
may be referred by the National Credit Regulator to the National Consumer Tribunal on the basis that they have lent recklessly as that concept is envisaged in Section $80(1)(b)\left(\right.$ ii) of the Act. ${ }^{86}$

In respect of the regard that should be had to the consumer's debt repayment history as consumer under credit agreements (which will usually be reflected on the credit record of the consumer as held by one or more credit bureaus), it was provided that credit providers must take into consideration all debt, including monthly debt repayment obligations in terms of credit agreements, as reflected on the prospective consumer's credit profile held by a credit bureau, when calculating the prospective consumer's allocatable income and discretionary income and in making an affordability assessment. ${ }^{87}$ This affordability assessment calculation must include the minimum payments due under credit facilities. ${ }^{88}$ In addition, credit providers must ensure that these requirements are performed during the 7 business days immediately prior to the initial granting of credit or to the increasing of a credit limit. ${ }^{89}$

Guidelines on 'Avoiding double counting in calculating allocatable income' provided that where credit agreements are entered into on a substitutionary basis, in order to pay off one or more existing credit agreements, credit providers should record that the credit being applied for is to replace other existing credit agreement/s and take reasonable steps to ensure that such credit is properly used for such purpose. ${ }^{90}$ Guidelines on Credit Literacy were also laid down as part of the September 2013 Draft Guidelines, ${ }^{91}$ namely that credit providers must take reasonable steps to display such credit literacy posters and make available such credit literacy materials to their clients and prospective consumers, as the National Credit Regulator may issue from time to time, ${ }^{92}$ and that credit providers must perform such credit literacy surveys as the National Credit Regulator may require from time to time. ${ }^{93}$

Finally it was laid down that the aforementioned September 2013 Draft Guidelines should be read with the Credit Provider's Code of Conduct to Combat Overindebtedness, also dated September 2013. ${ }^{94}$

Various problems manifested themselves during the initial years that the National Credit Act was in operation, as a result whereof, after seeing a formidable number of drafts, the NCA Amendment Act ${ }^{95}$ was eventually approved a couple of months after the September 2013 Draft Guidelines. The NCA Amendment Act inter alia introduces significant amendments to the assessment mechanisms and procedures set out in Section 82. In brief, it introduces an amendment to Section 48 of the National Credit Act, so that it now provides for the Minister to prescribe criteria and measures to determine the outcome (sic) of affordability assessments. ${ }^{96}$ The Minister must, on recommendation of the National Credit Regulator, make affordability-assessment

86. Par 5.2.4 of the September 2013 Draft Guidelines. All other credit agreements and more specifically 'Secured Credit Agreements' were excluded from this provision. 87. Par 5 and 6 of the September 2013 Draft Guidelines. The aforementioned principles with regard to debt repayment history under credit agreements also apply to joint prospective consumers or joint consumers.

88. Par 6.2 of the September 2013 Draft Guidelines. 89. Par 6.3 of the September 2013 Draft Guidelines.
90. Par 7.1 of the September 2013 Draft Guidelines. 91. Par 8.

92. Par 8.1 of the September 2013 Draft Guidelines. 93. Par 8.2 of the September 2013 Draft Guidelines. 94. Par 9.1 of the September 2013 Draft Guidelines. 95. See n 43 above.

96. S 15(c). Obviously the Minster cannot determine the outcome of these assessments but merely how the assessments must be conducted. 
regulations. ${ }^{97}$ Section 82(3) and (4) of the Act is deleted, and Section 82(1) and (2) substituted to provide that a credit provider may determine for itself the evaluative mechanisms or models and procedures to be used in meeting its assessment obligations under Section 81, provided that any such mechanism, model or procedure results in a fair and objective assessment, which must not be inconsistent with the affordability assessment regulations ${ }^{98}$ made by the Minister. ${ }^{99}$

The effect of the aforesaid amendments will be that the evaluative models used by credit providers will have to be aligned with the affordability assessment regulations issued by the Minister. Once issued by way of regulations, these affordability assessment 'guidelines' will thus be binding on credit providers, contrary to the previous position under Section 82(3) that guidelines published by the National Credit Regulator were not binding. The deletion of Section 82(4) will also mean that the Tribunal cannot hear matters where it is alleged that the credit provider failed to meet its assessment obligations under Section 81 or used evaluative methods that did not result in fair and objective assessment.

The affordability assessment regulations will accordingly provide a benchmark against which a credit provider's compliance with its pre-agreement assessment duty in terms of Section 81 will be measured. They will, as a minimum, lay down certain standard requirements, in which such assessments will have to meet in order to pass the obligation of the credit provider to refrain from reckless credit granting.

On 1 August 2014, a comprehensive set of draft regulations on various matters, including regulations on affordability assessment, were published for public comment. ${ }^{100}$ Chapter 1 of the aforesaid regulations contains the following amplified and expanded set of definitions: 'Allocatable income' is more comprehensively defined than in the September 2013 Draft Guidelines and means gross income less statutory deductions, such as income tax, unemployment insurance and maintenance payments, less necessary expenses (as defined in the regulations). A definition of 'Credit Cost Multiple', which did not appear in the September 2013 Draft Guidelines, was also inserted and refers to the ratio of the total cost of credit to the advanced principal debt, that is, the total cost of credit divided by the advanced principal debt expressed as a number to two decimal places. 'Credit Profile' means the consumer's payment profile, including adverse information held by a credit bureau. 'Payment profile' means a payment profile as defined in Regulation 17(5), namely that it refers to a consumer's repayment history in respect of a particular transaction.

97. S 24 of the NCA Amendment Act (n 43).

98. Authors' emphasis.

99. S 24 of the NCA Amendment Act (n 43). See also s 15(b) of the NCA Amendment Act which provides for the amendment of the current s 48 to the effect that with regard to registration of credit providers, the compliance by a credit provider with a prescribed code of conduct as well as the affordability assessment regulations made by the Minister on the recommendation of the National Credit Regulator may be considered.

100. Government Notice R. 597 in Government Gazette 37882 of 1 August 2014-hence, the '2014 Draft Regulations'. 
The definition of 'Discretionary income' was also amplified to mean gross income less statutory deductions, such as income tax, unemployment insurance fund, maintenance payments less necessary expenses (at a minimum defined in the regulations); less all other committed payment obligations including such as may appear from the credit applicant's credit records as held by any credit bureau which income is the amount available to fund the proposed credit instalment. 'Gross income' means all income earned without deductions from whatever source. 'Joint consumers' means consumers that are co-principal debtors who are jointly and severally liable with regard to the same credit agreement and apply jointly for the credit agreement, excluding the surety or a credit guarantor under a credit guarantee. The exclusion of consumers married in community of property who apply separately for credit which appeared in the September 2013 Draft Guidelines was omitted from the aforesaid definition. 'Necessary expenses' are more comprehensively defined than in the September 2013 Draft Guidelines, which only referred to expenses in regard to food, transport and accommodation, to mean the 'consumer's minimum living expenses as determined in accordance with regulation $23 \mathrm{~A}(9)$ together with any other necessary living expenses excluding debt repayments'. The definitions regarding unsecured term credit agreements and secured term credit agreement which appeared in the September 2013 Draft Guidelines were omitted from the 2014 Draft Regulations.

In the context of affordability assessment, the 2014 Draft Regulations amend the National Credit Regulations ${ }^{101}$ that were issued when the Act came into operation (and which did not include affordability assessment guidelines), inter alia by the insertion of Regulation 23A entitled 'Criteria to conduct Affordability Assessment'. The regulations apply to current, prospective and joint consumers, all credit providers and all credit agreements to which the Act applies (subject to Regulation $23 \mathrm{~A}(2)) .{ }^{102}$ Similar to the September 2013 Draft Guidelines, it is stated that the regulations do not apply where the consumer is a juristic person, and it excludes all the credit agreements previously excluded by the September 2013 Draft Guidelines from its ambit. ${ }^{103}$ It, however, expands on the excluded credit agreements mentioned in the September 2013 Draft Guidelines, by providing that the regulations do not apply to any change to a credit agreement and/or any deferral or waiver of an amount under an existing credit agreement $^{104}$ or to Mortgage Agreements that qualify for the Finance Linked Subsidy Programs developed by the Department of Human Settlements and credit advanced for housing that falls within the threshold set from time to time. ${ }^{105}$

With regard to existing 'financial means and prospects', the 2014 Draft Regulations, similar to the September 2013 Guidelines, stipulate that a credit provider must take practicable steps to assess the consumer or joint consumers' allocatable income as well as their discretionary income, to determine whether the consumer has the financial means and prospects to pay the proposed credit instalments. ${ }^{106}$ Similarly, it also provides that a credit provider is required to take steps to validate gross income by referring to the consumer's recent 3 months pay slips, recent 3 months bank

101. n 51.

102. Reg 23A(1).

103. $\operatorname{Reg} 23 \mathrm{~A}(2)(\mathrm{a})-(\mathrm{i})$.
104. In accordance with s 95 of the Act-reg 23A(2)(j).

105. $\operatorname{Reg} 23 \mathrm{~A}(2)(\mathrm{k})$.

106. Reg $23 \mathrm{~A}(3)$. 
statements and any other similar credible information. ${ }^{107}$ Where the consumer's monthly gross income shows material variance, the average gross income over the period of not less than 3 months preceding the credit application must be utilised. $^{108}$

However, it should be noted that the 2014 Draft Regulations refer to 'practicable' steps instead of 'reasonable' steps, as was indicated in the September 2013 Draft Guidelines and required by Section 81 of the Act.

The 2014 Draft Regulations oblige the consumer to accurately disclose to the credit provider all financial obligations to enable the credit provider to conduct the affordability assessment. ${ }^{109}$ The consumer is further obliged to disclose authentic documentation for purposes of the affordability assessment. ${ }^{110}$ Insofar as the consumer's existing financial obligations are concerned, the credit provider is required to make a calculation of the consumer's existing financial means, prospects and obligations as envisaged in Sections 78(3) and 81(2)(a)(iii) of the Act. ${ }^{111}$ More or less similar to the September 2013 Draft Guidelines, the credit provider may, however, on an exceptional basis, where justified, accept the consumer's declared necessary expenses, which are lower than those set out in a revised Table $1^{112}$ (which sets out specific information based on the consumer's monthly (and not annual) gross income bands that differ appreciably from those in the September 2013 Draft Guidelines). However, this may only be performed if a questionnaire ${ }^{113}$ (and not merely credible written evidence as required by the September 2013 Draft Guidelines) is completed by the consumer or joint consumers. ${ }^{114}$

107. $\operatorname{Reg} 23 \mathrm{~A}(4)$.

108. Reg $23 \mathrm{~A}(5)$.

109. Reg $23 \mathrm{~A}(6)$. The word 'must' is used.

110. Reg 23A(7). The word 'must' is used.

111. Reg 23A(8). This calculation must also be done for applications that relate to the extension of existing credit agreements.

112. (Revised) Table 1: necessary expense norms.

\begin{tabular}{|c|c|c|c|}
\hline $\begin{array}{l}\text { Monthly gross } \\
\text { income }\end{array}$ & & $\begin{array}{l}\text { Minimum } \\
\text { monthly } \\
\text { fixed factor }\end{array}$ & $\begin{array}{l}\text { Monthly Fixed } \\
\text { Factor }+0 \% \text { of } \\
\text { Income Above } \\
\text { Band Minimum }\end{array}$ \\
\hline Minimum & Maximum & & \\
\hline R 0.00 & $\begin{array}{l}\mathrm{R} 800.00 \\
/ \pm \mathcal{E}_{45,60}\end{array}$ & R 0.00 & $100 \%$ \\
\hline R800.01 & $\mathrm{R} 6,250.00$ & R800.00 & $6.75 \%$ \\
\hline$/ \pm f^{45.60}$ & $/ \pm £ 356.25$ & $/ \pm f^{45.60}$ & \\
\hline R6,250.01 & $\mathrm{R} 25,000.00$ & $\mathrm{R} 1,541.67$ & $9.00 \%$ \\
\hline$/ \pm £ 356.25$ & $/ \pm £ 1425$ & $/ \pm £ 87.83$ & \\
\hline $\mathrm{R} 25,000.01$ & R50,000.00 & R3,375.00 & $8.20 \%$ \\
\hline$/ \pm f_{1425}$ & $/ \pm £ 2850$ & $/ \pm f_{1} 192.37$ & \\
\hline $\begin{array}{l}\mathrm{R} 50,000.01 \\
/ \pm £ 2850\end{array}$ & Unlimited & $\begin{array}{l}\mathrm{R} 5,425.00 \\
/ \pm £ 309.22\end{array}$ & $6.75 \%$ \\
\hline
\end{tabular}

113. Annexure B to the 2014 Draft Regulations contains the 'Declaration of Consumer's necessary expense questionnaire'. The questionnaire includes a declaration whereby the consumer/s completing the questionnaire is reminded that in terms of section 81(1) of the National Credit Act when applying for a credit agreement and while that credit agreement is being considered by the credit provider, the prospective consumer must fully and truthfully answer any requests for information made by the credit provider as part of the assessment and that misrepresentation of facts will be dealt with in terms of the applicable law. Part 1 of the questionnaire deals with the consumer's details. Part 2 addresses the consumer's necessary expenses and requires the consumer to indicate the relevant income band that applies to him and to set out the amount of his declared monthly expenses. Part 3 provides for the consumer to disclose in detail his expenses in respect of accommodation, transport, food, education, medical costs, water and electricity and maintenance. 114. $\operatorname{Reg} 23 \mathrm{~A}(9)$. 
The 2014 Draft Regulations further prescribe that when conducting the affordability assessment, a credit provider must calculate the consumer's allocatable and discretionary income, taking into account all debts, including monthly debt repayment obligations in terms of credit agreements as reflected on the consumer's credit profile held by a registered credit bureau and taking into account maintenance obligations arising from statutory deductions or necessary expense. ${ }^{115}$

With regard to the consumer's debt repayment history as a consumer under credit agreements, the regulations oblige the credit provider to take such history into account as envisaged in Section 81(2)(a). It must further be ensured that this requirement is performed within 7 business days immediately prior to the initial granting of credit or the increasing of an existing credit limit and within 14 business days with regard to mortgages. ${ }^{116}$

For purposes of avoiding double discounting in calculating the consumer's allocatable income, a provision similar to that in the September 2013 Draft Guidelines is contained in the 2014 Draft Regulations. ${ }^{117}$ In addition, it is prescribed, with regard to disclosure of credit cost multiple and the total cost of credit, ${ }^{118}$ that a credit provider must disclose to the consumer the credit cost multiple and total cost of credit in the pre-agreement statement and quotation. ${ }^{119} \mathrm{It}$ must be ensured that the credit cost multiple disclosures for credit facilities must be based on 1 year of full utilisation up to the credit limit proposed, and that the attention of the prospective consumer is drawn to the credit cost multiple and that the cost of credit, as disclosed, is understood by the consumer. ${ }^{120}$

The 2014 Draft Regulations also introduce a new right for the consumer regarding the outcome of an affordability assessment: a consumer who is aggrieved by the outcome of affordability assessment may at any time lodge a complaint in terms of Section $134^{121}$ or $136^{122}$ of the National Credit Act with the credit provider for dispute resolution. ${ }^{123}$ The credit provider is then obliged to resolve the complaint within 14 days. ${ }^{124}$ If the grievance is not addressed by the credit provider, the consumer can approach the National Credit Regulator. ${ }^{125}$

It is important to note that the 2014 Draft Regulations do not make any specific distinction between unsecured term credit agreements and secured term credit

115. $\operatorname{Reg} 23 \mathrm{~A}(10)$.

116. Reg 23A(11). Although not specifically stated it appears that one can safely assume the legislature meant within 14 business days immediately prior to entering into a mortgage agreement.

117. $\operatorname{Reg} 23 \mathrm{~A}(12)$.

118. 'Cost of credit' is not defined in the regulations. S 101 of the NCA deals with cost of credit and sets out the various costs that may be charged in respect of a credit agreement to which the Act applies. See Renke LLD thesis (n 9) $489 \mathrm{ff}$.

119. Reg $23 \mathrm{~A}(13)$ (a). The total cost of credit that must be disclosed may include the principal debt, interest, initiation fee (if any), service fee aggregated to the life of a loan and credit insurance (depending upon discretion of the consumer aggregated to the life of a loan) - reg $23 \mathrm{~A}(13)(\mathrm{d})$.

120. Reg $23 \mathrm{~A}(13)(\mathrm{b})$ and (c).

121. S 134 provides for alternative dispute resolution.

122. S 136 provides that any person may submit a complaint regarding an alleged contravention of the Act to the National Credit Regulator in the prescribed manner and form. It further provides that the National Credit Regulator may initiate a complaint in its own name.

123. $\operatorname{Reg} 23 \mathrm{~A}(14)(\mathrm{a})$.

124. Reg 23A(14)(b).

125. Reg $23 \mathrm{~A}(14)(\mathrm{c})$. 
agreements for purposes of the Section 81 assessment, and it specifically does not contain a provision similar to the September 2013 Draft Guidelines that a credit provider who enters into an unsecured term credit agreement where the consumer's living expenses are below the prescribed limit may be charged with reckless lending. ${ }^{126}$ However, Chapter 6 of the 2014 Draft Regulations further contains an unnumbered provision which stipulates that the regulations are binding to the extent of their application and that failure by the credit provider to comply will inter alia amount to prohibited conduct or reckless lending conduct and failure to comply by the consumer will inter alia amount to misrepresentation.

Finally, in the context of the pre-agreement assessment as required by the National Credit Act and the regard it requires to be had to the consumer's debt repayment history, it should be noted that Section 69 of the Act provides for the establishment of a National Register of Credit Agreements to which credit providers must report details regarding the consumer and the specific credit agreement upon entering into or amending a credit agreement. ${ }^{127}$ The credit provider must also report the particulars of the termination and satisfaction ${ }^{128}$ of any agreement so reported as well as instances where a transfer of rights has occurred. ${ }^{129}$ In the alternative to reporting to the National Credit Register, credit providers are obliged to report such information to a credit bureau registered in terms of the Act. ${ }^{130}$ Currently, a national register as envisaged in Section 69 has not yet been established, and credit providers thus report the necessary information on credit agreements to a number of credit bureaus. Not only positive information, but also adverse information such as the granting of judgments in respect of credit agreements is reported to these credit bureaus. Unfortunately, not all credit providers comply with this reporting obligation with the result that the consumer's profile with the credit bureaus might not necessarily be 100 per cent accurate.

Notice should also be taken of the 'Removal of Adverse Consumer Credit Information and Information relating to Paid Up Judgments Regulations', ${ }^{131}$ which came into effect on 1 April 2014. In terms thereof, a registered credit bureau is obliged to remove adverse credit information ${ }^{132}$ as reflected on a consumer's

\footnotetext{
126. See par 5.2.4 of the September 2013 Draft Guidelines.

127. S 69(2)(a) to (e) sets out the information that must be reported.

128. S 69(3).

129. S $69(4)$.

130. S 69 read with s 43 .

131. Published in Government Gazette 37386 of 26 February 2014-hence, the 'Credit Amnesty Regulations'. It is to be noted that the Department of Trade and Industry has also proposed that certain amendments be made to the Magistrates' Courts Act 32 of 1944 to effectively deal with the rescission or abandonment of judgments as a mechanism for granting credit information amnesty. See further Working document, 'Magistrates' Court Amendment Bill', (21 February 2013), available at http://www.rebels.co.za, 'accessed on 5 September 2013'.

132. Reg 1 of the Credit Amnesty Regulations defines 'adverse consumer credit information' to mean
}

(a) adverse classifications of consumer behaviour are subjective classifications of consumer behaviour and include classifications such as 'delinquent', 'default', 'slow paying', 'absconded' or 'not contactable';

(b) adverse classifications of enforcement action, which are classifications related to enforcement action taken by the credit provider, including classifications such as 'handed over for collection or recovery', 'legal action' or 'write-off';

(c) details and results of disputes lodged by consumers irrespective of the outcome of such disputes;

(d) adverse consumer credit information contained in the payment profile represented by means of any mark, symbol, sign or in any manner or form. The concept 'adverse consumer credit information' as per the Credit Amnesty Regulations is thus broader than that contained in regulation 17(3) and (4) of the National Credit Regulations (n 51). 
records held by it as at the effective date of the regulations and information relating to paid up judgments ${ }^{133}$ on an ongoing basis. ${ }^{134}$ Such adverse consumer credit information and information relating to paid up judgments must be removed within a period of 2 months from the effective date of the aforesaid Credit Amnesty Regulations. ${ }^{135}$ Regulation 2(h) further provides that during the 2 month period contemplated in Regulation 2(b), a registered credit bureau must ensure that the adverse consumer credit information and information relating to paid up judgments that are required to be removed are not displayed or provided to credit providers or any person requesting such information. After the 2-month period mentioned in Regulation 2(b), a registered credit provider is obliged to remove information relating to paid up judgments within 7 days after receiving proof of such payment. ${ }^{136}$ Credit providers are also tasked by Regulation 3 to submit information regarding paid up judgments and adverse consumer credit information to the credit bureau. It is inter alia expressly stated that a credit provider must not use adverse consumer credit information and information relating to paid up judgments that have been removed in terms of these regulations for any reason, including credit scoring and assessment. ${ }^{137}$

\section{Discussion}

\section{A. General comments on the evolution of the South African responsible lending regime ${ }^{138}$}

The framework for the compulsory pre-agreement assessment to prevent reckless credit in terms of the National Credit Act progressed from the bare requirements cast in Section 81, which required consideration of the consumer's level of understanding of his risks, cost and obligations, his debt repayment history and his existing financial means, prospects and obligations without specifying the detail of such assessment, to one that is comprehensive and detailed. The approach with regard to pre-agreement assessment has clearly become more interventionist as is evident in the move from non-binding guidelines towards regulations that, once put into operation, will be binding on credit providers as minimum standards for assessment.

The May 2013 Draft Guidelines, ${ }^{139}$ being the first concrete steps towards clarifying the requirements for a Section 81 assessment, was basically a 'wish list' that did not contain much detail regarding the requirements for the assessment, although it served to clarify the direction that the Regulator proposed to take as the first guideline pre-empted the introduction of the calculation norms in the September 2013 Draft Guidelines. ${ }^{140}$ The requirement of comprehensive consid-

133. Reg 1 of the Credit Amnesty Regulations defines 'paid up judgments' to mean 'civil court judgment debts, including default judgments, where the consumer has settled the capital amount under the judgment(s)'. 134. Reg 2(a) of the Credit Amnesty Regulations. 135. Reg 2(b) of the Credit Amnesty Regulations. 136. Reg 2(i) of the Credit Amnesty Regulations. 137. Reg 3(d) of the Credit Amnesty Regulations. Authors' emphasis. It should be noted that reg 5 of the Credit Amnesty Regulations provides that 'irrespective of the removal of adverse credit information from a consumer's credit record, the consumer remains liable to meet his obligations in terms of the credit agreement'.

138. Discussed in par II in the preceding citation. 139. n 68.

140. n 69. 
eration of all the consumer's expenses and debt repayments that it proposes would enable the credit provider to have regard to a consumer's complete debt situation, which would provide a clearer picture of whether the consumer could afford the proposed credit. The introduction of a substantial adversity buffer ${ }^{141}$ when calculating the consumer's discretionary income that could be applied towards payment of the proposed credit represents a sound move towards shielding a consumer against over-indebtedness. The expansion on the credit provider's assessment obligations by requiring credit providers to consult and to share credit application information will clearly allow for more accurate assessments. The imposition of a time limit on the assessment also serves as a cautionary measure to limit the opportunity for a consumer to enter into other credit agreements without the agreement in respect of which the assessment is conducted having been loaded onto the consumer's credit profile, thereby limiting the incidence of consumers obtaining further reckless credit as a result of an incomplete credit profile.

The regulatory reach of the assessment guidelines were expanded by the September 2013 Draft Guidelines, which not only provided for definitive calculation norms but also imposed guidelines relating to credit literacy, thus addressing means to increase consumer awareness and achieve better understanding of the implications of credit thereby serving to prevent the incidence of reckless credit granting to a consumer who does not understand his risks, costs and obligations under a credit agreement. These Guidelines also clearly sought to address the risk of reckless credit granting in the context of unsecured credit agreements, which has been a major reason for the recent adversity that befell African Bank, causing the South African Reserve Bank to place African Bank under curatorship. ${ }^{142}$ However, the distinction between unsecured and secured term credit agreements for purposes of constituting reckless credit where the credit was granted to a consumer who disclosed necessary living expenses below the minimum for his income band, but without credible proof, appears to be forced. The presence of security is not a failsafe indicator that the credit was not recklessly granted, and it is submitted that the presence of security bears no relevance on whether credit was granted recklessly or not if no pre-agreement assessment was carried out or the consumer did not understand his risks, costs and obligations under the agreement or the consumer could in any event not afford the credit.

With regard to the requirement in the September 2013 Draft Guidelines that the credit provider must take all the consumer's debt into account as reflected on the credit bureau profile, it should be pointed out that cognisance ought also to be taken of the fact that a consumer may have other debt that may impact on his ability to afford credit, which will not appear on his credit bureau record and

141. Analogous to s 9(1) Credit Agreements Act 75 of 1980, one of the NCA's immediate predecessors (n 29). 142. G Jones, 'African Bank in curatorship: sharing the pain', Financial Mail (14-20 August 2014) 24 ff, available at www.financialmail.co.za. In a media release, the South African central bank also announced an investigation into African Bank, inter alia to ascertain whether or not it appears that any business of the latter was conducted recklessly. See https://www.resbank.co. za/Publications/Detail-Item-View/Pages/Publications.aspx? sarbweb=3b6aa07d-92ab-441f-b7bfbb7dfbl bedb4\&sarblist=2 1b5222e-7 125-4e55-bb65$56 f d 3333371$ e\&sarbitem $=6396$, 'accessed on 4 September 2014'. 
that in order to have a complete picture of the consumer's debt situation, the credit provider ought to ask the consumer to indicate any other debts not reflected on his credit profile and provide details of same.

The guideline that a credit provider is not required to verify the consumer's living expenses unless they fall below the minimum in Table 1 will ease the credit provider's burden to obtain information regarding the consumer's living expenses. The calculation norms based on the income bands as contained in Table 1 of the September 2013 Draft Guidelines, however, attracted severe criticism in view thereof that they would foreclose a significant portion of the population, namely those consumers who fell within the income band below R14 000 per year, ${ }^{143}$ from access to credit. ${ }^{144}$ It was surmised that consumers who would be cut off from access to credit would be forced to go 'underground' and thus would have to resort to loan sharks who would be prepared to grant them credit at exorbitant interest rates. ${ }^{145}$

The 2014 Draft Regulations ${ }^{146}$ have both positive as well as negative features. It is to be welcomed that the said Regulations have not sought to retain the distinction made in the September 2013 Draft Guidelines in respect of unsecured and secured credit agreements, and it also did not retain the provision that unsecured credit granted to consumers whose necessary expenses fall below those prescribed by Table 1 without credible supporting evidence constitute reckless credit. The requirement that 'practicable' steps be taken by the credit provider to assess the consumer's allocatable and discretionary income is contrary to the obligation imposed by the National Credit Act in Section 81 which requires 'reasonable steps' to be taken, and the wording of the Regulations will thus have to be revised to align it with the wording in the Act. The requirement in the 2014 Draft Regulations, as was also contained in the September 2013 Draft Guidelines, that the credit provider validates the consumer's gross income is inarguably a sine qua non for proper assessment. It is further to be welcomed that the range of expenses to be taken into account for purposes of calculating the consumer's living expenses has been significantly broadened beyond food, accommodation and transport as indicated in the September 2013 Draft Guidelines, and the 2014 Draft Regulations accordingly represent a more realistic consideration of all the types of living expenses borne by consumers. The retaining of the minimum living expense standards for specified income bands, however, has a janus-faced quality: on the one hand it can be lauded for preventing reckless credit granting to consumers who cannot afford credit and mislead the credit provider about their living expenses in a bid to obtain credit, whereas on the other hand, it may be argued that such minimum living expenses may be exclusionary in nature and that a more individualised approach where no standard minimum living expenses are imposed would make for more

143. £798 per year.

144. Compuscan Presentation on 'Amnesty and Affordability Guidelines', available at www.compuscan. co.za, 'accessed on 24 June 2014'.
145. Compuscan Presentation (n 144). 146. n 100. 
accurate and less exclusionary assessment. However, on a more positive note, it may be remarked that at least Table 1, as it originally appeared in the September 2013 Draft Guidelines, has been revised and tapered down to set calculation norms, which may be perceived as more realistic and less exclusionary with regard to consumers who may access credit. The introduction of a questionnaire to 'verify' living expenses that are less than that which are provided for in Table 1 adds a good measure of flexibility to the assessment process and serves a dual purpose, namely to ensure that credit is not extended to consumers who present a toned down and inaccurate version of their living expenses in order to obtain credit but also to make it possible for consumers who are able to prove that their minimum living expenses fall below the amounts stated in the Regulations, to obtain credit.

The 2014 Draft Regulations also expand on the obligations of the consumer with regard to pre-agreement assessment, as it adds to the requirement that the consumer answer fully and truthfully as set out in Section 81 of the Act, an obligation on the consumer to accurately disclose to the credit provider all financial obligations (thus also those that do not appear on his credit profile), to enable the credit provider to conduct an affordability assessment. This gives recognition to the fact that to impose responsible lending obligations on the credit provider without at least providing for some responsible borrowing obligations on a consumer defies the reality that whereas credit providers may be largely instrumental in granting reckless credit, consumers also play a role in many instances of reckless credit granting by not participating in good faith in the assessment process and not disclosing accurately all their financial obligations. It is, however, submitted that the distinction of 7 business days and 14 business days within which to refer to the consumer's debt repayment history appears artificial and the longer period afforded with regard to mortgage agreements might just increase the risk of reckless lending.

Although the 2014 Draft Regulations do not contain provisions relating to consumer literacy in the same terms as the September 2013 Draft Guidelines, it should be noted that it does impose the obligation on the credit provider to ensure that the attention of the consumer is drawn to the credit cost multiple and that the cost of credit is understood by the prospective consumer. Consequently, although it does not address the risks and obligations under the agreement specifically, it at least seeks to ensure that the consumer understands the costs (which arguably may also constitute a risk to the consumer) and may thus contribute towards decreasing the incidence of reckless credit granting on the basis that a consumer did not understand the costs of credit as envisaged by Section $80(1)(b)(i)$.

The introduction of a right for the consumer to lodge a complaint against the credit provider because he is aggrieved by the outcome of an affordability assessment is new and apparently seeks to ensure that consumers are not foreclosed from accessing credit because of an unfavourable outcome of an assessment that for instance failed to take cognisance of certain aspects required by the 2014 Draft 
Regulations. It can, however, be expected that credit providers will be opposed to retaining this provision in the 2014 Draft Regulations because, although the Regulations would set a minimum standard that the affordability assessment should meet, it would still be open to a credit provider to apply additional requirements and to extend credit that meets its risk appetite. ${ }^{147}$ It might also be argued that this provision is contrary to the clear provisions of Section 60 of the Act, which give the consumer a right to apply for credit, and Section 62, which gives the consumer the right to reasons for refusal of credit but neither of which gives the consumer a right to acquire credit. In any event, this provision may likely also not serve the interests of the consumers whom it seeks to protect as they may become embroiled in lengthy proceedings during which period they are in any event without the credit they sought.

Kelly-Louw commented on the May 2013 Draft Guidelines and expressed some valid reservations inter alia that the introduction of fixed percentages of discretionary income in accordance with specified income bands might unnecessarily marginalise certain consumers and cut them off from access to credit. ${ }^{148}$ She furthermore indicated that this type of fixed percentage model also does not cater for consumers who are willing to scale down their living standard in order to afford the credit. ${ }^{149}$ It appears that the aforementioned concerns have subsequently been addressed to a considerable extent insofar, as the income bands in Table 1 of the 2014 Draft Regulations ${ }^{150}$ are much less exclusionary than those proposed in the September 2013 Draft Guidelines. ${ }^{151}$ The Regulations also introduce the opportunity for consumers to escape the restrictions of the required minimum living expenses that must be taken into account by the credit provider for purposes of assessment by allowing the consumer to prove that his living expenses are below the minimum living expense standard. Notably, however, the Regulations introduce checks and balances on an allegation by a consumer that his living expenses fall below the minimum for his specific income band by requiring the consumer to provide details of his living expenses in a questionnaire and requiring the credit provider to ensure that the questionnaire is completed and considered before extending credit to such a consumer.

At this stage, it is submitted that it is unclear exactly what impact the Credit Amnesty Regulations ${ }^{152}$ may have on the credit provider's ability to conduct a proper assessment, even if the credit provider religiously sticks to the requirements set out in the 2014 Draft Regulations. The reason for this submission is that it is not the likelihood of the consumer defaulting at some future stage that causes reckless lending under the NCA but inter alia the fact that the consumer becomes over-indebted the moment that he enters into the ill-fated agreement.

147. S 61(5), discussed in par II in the preceding citation, is also of importance in this respect.

148. Kelly-Louw (n 40) 36.
149. Kelly-Louw (n 40) 36 .

150. n 112.

151. n 82.

152. n 131 . 
Whether the 2014 Draft Regulations will eventually be retained and issued in their current format remains to be seen, but at least one thing is clear: the South African Regulator is taking giant interventionist strides in the conduct of pre-agreement assessment as a measure to prevent reckless lending and subsequent over-indebtedness.

\section{B. Responses to certain comments made by Wilson regarding the South African responsible lending regime}

Some of the specific observations Wilson makes with regard to the South African reckless lending regime ${ }^{153}$ merit further comment, as it unfortunately provides a distorted view of the South African position. In the first instance, it should be pointed out that Wilson indicates that the concept of reckless lending 'undoubtedly refers to conduct more egregious than providing credit in circumstances where it might be unsuitable for a consumer's needs' ${ }^{154}$ She uses this premise and the fact that reckless lending in South Africa is linked to over-indebtedness to conclude that the use of the word 'reckless' will lead to a more restrictive interpretation of the types of lending that will offend the National Credit Act. ${ }^{155}$ However, she fails to provide a complete picture of the type of conduct that constitutes reckless lending as described in Section 80 of the Act, namely that it also occurs where no proper assessment is conducted or where, despite an assessment, the consumer did not understand his risks, costs and obligations under the credit agreement - thus evidencing that the use of the word 'reckless' has a broader reach than that surmised by Wilson. That having been said though, the South African legislature should possibly consider substituting the word 'reckless' with 'irresponsible' to bring it more in line with international terminology.

It should also be noted that Wilson indicates, with reference to the obligation on the consumer to answer fully and truthfully during a Section 81 assessment, that the South African regime includes an 'unfortunate focus on responsible borrowing'. ${ }^{156}$ As has been demonstrated earlier, the South African reckless lending regime imposes an onerous pre-assessment obligation on a credit provider in order to prevent the granting of reckless credit. In tandem with these obligations, the consumer is required to cooperate in the assessment by providing full and truthful answers as the consumer is the person with comprehensive peculiar knowledge regarding his financial situation that may impact on the assessment, and the credit provider, while consulting the consumer's credit profile and debt repayment history, may not be privy to other information that may be relevant and which does not appear on such profile. In any event, account has to be taken of the fact that some safety valve should be built into a lending regime that factors in the possibility that a consumer may lie to or mislead a credit provider, thus materially impacting 
on the credit provider's ability to make an accurate assessment. Wilson's classification of the South African reckless lending regime as focusing on responsible borrowing is therefore misconceived as it is clear that the focus is far more on compliance by credit providers with responsible lending practices.

Wilson also appears to be misguided in her perception that under the South African legislation, any breaches in the reckless lending provisions must be pursued by the affected borrowers themselves, thus implying that in this regard, the legislation is a 'toothless tiger'. ${ }^{157}$ As indicated earlier, the consumer is protected in the sense that although reckless credit granting may be pursued as a cause of action, it can also function as a defence, and case law demonstrates that this is how it has been relied upon by South African consumers - thus relieving them of the burden to pursue litigation by rather using it as a defence when litigated against, thus leaving it to the credit provider to institute action to enforce an agreement. In addition, the power of the Tribunal to impose an administrative fine and to cancel a credit provider's registration also enhances consumer protection. It should also be noted that the NCA Amendment Act $^{158}$ has now bestowed comprehensive powers relating to declarations of reckless credit on the National Consumer Tribunal with the result that cheap and speedy access to justice is now to the consumer's avail.

Wilson typifies the South African reckless lending regime as 'reactive' in the sense of responding to market failures and not seeking to go beyond what is perceived as necessary in that response. An appreciation of the South African reckless lending regime, however, makes it clear that to typify such regime as merely reactive would disregard its innovative and pro-active measures in combating reckless lending.

Although a detailed discussion of the office and functions of the National Credit Regulator is beyond the scope of this contribution, it will suffice to peripherally remark that the establishment of the National Credit Regulator, being a wellresourced Regulator that is tasked specifically to oversee the South African credit market, has yielded many benefits in curbing exploitative practices by credit providers and monitoring and sanctioning the incidence of reckless credit granting. ${ }^{159}$

As indicated, Wilson uses four criteria to benchmark the likely effectiveness of responsible lending regimes. ${ }^{160}$ Measured against these criteria, the following can be observed regarding the South African responsible lending regime:

(a) It is clear that the South African regime's main focus is on responsible lending, rather than responsible borrowing.

(b) The focus of the South African responsible lending regime is on consumer credit in general and is not limited to residential mortgage loans.

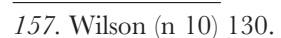

158. n 43.

159. The National Credit Regulator is established in terms of $\mathrm{s} 12$ of the NCA and has jurisdiction throughout the Republic of South Africa (s 12(1) (a)). In terms of s 12 the National Credit Regulator, which is governed by a Board (s 19), is an independent statutory body which is subject only to the
Constitution of the Republic of South Africa, 1996 and the law. The National Credit Regulator possesses various powers, including registration (s 14) and enforcement powers (s 15). For a detailed discussion of the National Credit Regulator, see JW Scholtz, 'Consumer credit institutions' in 'Scholtz Commentary' (n 42) par 3.2.

160. Par I. 
(c) The recent developments regarding credit assessment practices show that the assessment processes are individualised and have a measure of flexibility built into it in order to minimise financial exclusion. However, it is conceded that such measures of flexibility could be improved.

(d) An adequately resourced regulatory agency, the National Credit Regulator, exists, which properly monitors and enforces compliance with market conduct regulation, including responsible lending obligations.

\section{Conclusion}

Benchmarked against the four characteristics of an effective responsible lending regime as identified by Wilson, it is apparent that the South African reckless lending regime is no 'toothless tiger', and that it attaches the necessary amount of significance to the credit provider's duty to take reasonable steps to do a proper preagreement assessment in order to avoid reckless credit granting. It also recognises that the use of the pre-agreement assessment to prevent reckless credit granting will only be successful where it has clear parameters and operates in tandem with other measures, such as proper sanctions for reckless lending. It further recognises that responsible lending and responsible borrowing go hand in hand, and although the obligations it imposes on credit providers by far outweigh the obligations placed on consumers in this regard, it imposes appropriate duties on the parties. Consumers are protected and 'responsibilised' by this regime. Consequently, although the South African reckless lending regime, specifically in the context of pre-agreement assessment, can obviously still be refined in many respects, it can definitely not be said to be lagging behind more developed jurisdictions, such as those discussed by Wilson, in its endeavours to protect consumers against irresponsible lending. In South Africa, the recent developments that led to African Bank being placed under curatorship and the announcement that a high profile investigation is going to be conducted into the reasons for the Bank's financial problems has placed renewed emphasis on the fact that it is not only credit providers and consumers who play a role in the prevention of reckless credit granting, but that the regulator also has a duty to be vigilant and monitor compliance by credit providers with the prohibition against reckless lending. Prevention, indeed, is better than cure. 